\title{
The Two Door Perspective: An Assessment Framework for Open Government
}

\author{
Rodrigo Sandoval-Almazán
}

Universidad Autónoma del Estado de México (Autonomous University of the State of Mexico), Instituto Literario No. 100.

Toluca, México.rsandovala@uaemex.mx

527222140250

\begin{abstract}
The recent trend of open government in the world has created an avalanche of initiatives, metrics, and research paths. However these directions are usually random and dispersed. Governments around the world understand the trend with different perspectives, focus and theoretical approaches. Nevertheless the open government perspective is evolving step by step. This paper proposes an assessment framework to contribute on the line of reflection and understanding of open government initiatives. It also helps policymakers, stakeholders, practitioners and scholars to improve this field and spend public resources in a more accurate way. The paper is structured as follows: an introductory section that leads to the open government problem and the different directions it may take; a second section of literature review; a third section of the model proposal and a final section of discussion and future research.
\end{abstract}

Keywords: open government model, assessment open government, assess, metrics, systems

in he idea of openness in public administrations is not new. However the spreading use of information systems and technological advances in modern societies has attained new information demands and claims. Moreover, citizens are more aware about problems, policy making, debates and budget affairs than ever because this new trend of spreading information. Following this idea, the democratic participation (Heckmann, 2011) is evolving into a more interactive web relationship (Francesco De Angelis, 2010; Mantilla, 2009; Petrik, 2009) and general values of the public administration are evolving (Bannister, 2011). These changes are pushing the open government trends into several directions. Many governments have taken the notion of openness to introduce new policies and changes in the public administration, however very few of them have been aware of how important it is to open government data and what amounts and boundaries this openness has to be. In such a sense, the aim of this paper is to provide a direction to understand this trend, and help the government officials, scholars and practitioners to point their efforts following one possible direction. The structure of this paper will be: an introductory section that leads to the open government problem the different directions it may take; a second section of 
literature review; a third section of the model proposal and a final section of discussion and future research.

\section{Introduction}

Open government has become a confusing and ambiguous idea. The fast changing evolution of technologies and the widespread trend of electronic government around the world, has become the accelerator for this notion as the initiative of Open Government Partnership, or the Open Government Directive launched by the Obama's Administration on 2009 (White House, 2009), and the very recent Open Government License from the UK government (Government, 2011). This is one of the possible reasons for the misunderstanding. Another reason is that many governments, at different levels - local, state and federal - and with different degrees of development, have followed diverse directions and interpretations about the open government idea. These kinds of understanding lead to making mistakes in the operation level and to waste public funding on erroneous procedures and legal issues.

According to this, I have found at least three different directions that lead to the implementation of open government. The first direction and the main ground of open government is based on the Freedom of Information idea (Morris 1981). Also on this path McClean (2010) mentions the idea that after 1950 governments' documents should be available for anyone. Nevertheless it seems that due to the Cold War, this not possible and the government secrecy remained in the world until the eighties. This main direction is focused on the legal right that citizens have to access the government information. This information, produced by the public administration, must be considered as a part of the public domain (Chapman \& Hunt, 1986).

The second direction is to understand open government in the public administration sphere as a public information tool. In this direction, openness must be interpreted as the search to declassify information and stewardship of information; to improve the public decision-making and procurement information or deregulation. With a more operative and regulatory sense, this path operationalizes the open government idea in its public organizations.

The third direction, to understand the open government idea, is focused in a detailed part of information: data. The open data path will lead to opening the input or the gross data that is used for government officials and to keep it open for the citizen.

These three directions usually try to achieve accountability as a main goal. The processes of being transparent and the openness are supposed to lead to a more accountable government and for instance to a more legitimate government. There is a widespread idea that the legitimacy of the public authority depends, in some part, on its transparency (MacClean, 2010). However, this kind of legitimacy develops some perception of trust in the government. Even more this idea has increased the expectations of public officials and there is not enough evidence to prove this kind of relation between open government and trust. (Bannister \& Connolly, 2011) (Curtin \& Meijer, 2006). 
On the other hand, the term "transparency" closely related to open government, refers to which information about government processes and activities are accessible to citizens, reducing corruption and promoting accountability (Bertot, Jaeger, \& Grimes, 2010). Authors explicitly said:

"Looking beyond technological issues, the research on transparent and open government points to two critical success factors: 1) a culture of transparency embedded within the governance system and 2) a transparency "readiness" factor-that is, factors on the ground such as technology penetration, technology capabilities and access of government agencies, and social and technology readiness of the populace..." (Bertot, 2010 p. 286).

Above this differentiation that will be justified in the following section, this profusion of different paths and directions - that could be more than the ones mentioned here - creates different strategies and interpretations for the open government idea. In order to contribute to this discussion and present a different path that gathers and provides a systematic order to this vision, I propose the two door perspective to enhance and promote further discussion on this topic.

\section{Open Government Perspectives in the Literature}

A seminal work that includes several texts that are linked to the three main directions outlined previously is the book of Daniel Lathrop (Lathrop \& Ruma, 2010); where it is outlined that all contributions are important for the open government field. In the case of this research, it is remarkable in chapter two of Tim O'Reilly's writing, titled "Government as a platform", where he introduces this idea of the government data becoming feasible and accessible to citizens through information systems. The Beth Noveck contribution on chapter four "The single point of failure" summarizes some of her arguments of Wiki Government book and states the idea of decision making using open deliberation. Other chapters like Open Government and Open Society from Archon Fung and David Weil supports this idea of creating a common ground for open government. This literature review is based on the three directions to analyze open government field.

The first one is the freedom of information perspective. This idea emerges from Morris (1981) who promotes the idea of open government in the scientific field, arguing to release the information act in the US. Later on, other authors also presented similar ideas, finding the same difficulties as Morris stated in order to promote the open data in different intelligence agencies in the United States (Theoharis, 1982).

Similar efforts, pushing in order to achieve freedom of information and guaranteeing this idea as a main right, were developed around the world. In Norway, research in four Nordic countries found procedures to access official records. However it discusses the differences of this kind of freedom and others found in western countries like the right of anonymity and the freedom of press (Bertil, 1983). Similar troubles where found in the Japanese National Government which is described by Okudaira (1983). He analyzes the differences between the link of information freedom and the way that discretionary secrecy is provided to the agencies. Hubbertz's (1986) research of the Crown Corporation in Canada, as an agency exempt from the Canada's Access to Information Act is 
relevant to understand an exemption on the field and reveals some troubles in making public information as an open condition. This research is related to Relyea (1986) where he studied freedom of information in depth. His work is focused on congress members. Especially relevant is the attention to the electronic dissemination practices of information within federal agencies. Chapman's (1986) research in the United Kingdom points out the idea of freedom of information "Freedom of information is a fundamental human right and is the touchstone of all the freedoms to which the United Nations is consecrated; Freedom of information requires as an indispensable element the willingness and capacity to employ its privileges without abuse" (p.12).

In the European Community, Birkinshaw's (1997) research contributes defining the open and transparency concepts in government operations. This discussion shall homologate government practices in the new European Union and will become another impulse where the idea of freedom of information will be transformed into a new paradigm named open government. This will help to build the ICT and eGovernment: European Action Plan 2011-2015 (Comission, 2011).

An example for the second direction is to understand open government as an information tool. Curtin (2006) proposes three assumptions from government policy documents to operationalize this idea of freedom of information: 1. Transparency strengthens input legitimacy; 2. Output legitimacy, and 3. Social legitimacy. The author concludes that transparency is important for democratic purposes but there is no strong evidence related to legitimacy. On the other hand, the research of Grimmelikhuijsen (2010) who researched local government websites measuring the link between transparency and trust found that people who were exposed to more information were significantly more negative regarding perceived competence of the local council. And the people that received less information had the perception that the council was less honest. According to this, the relationship between transparency and trust is influenced partly, according to Grimmelikhuijesen, by the perceived credibility of the message on the website. Also, previous knowledge from citizens determines the judgment for a more open government. This research (between the link of legitimacy and trust through the open government idea) is still on debate among different scholars (Hazell \& Worthy, 2010; Hood, 2011; Jaeger \& Bertot, 2010). There is not enough evidence to discard this link or to present it as a real one. A new light contributing to this debate is the Bannister \& Connolly (2011) framework for trust and transformational government, which could help to define the trust perspective and to insert in a better way this idea about e-government and open government initiatives. Nevertheless this analytical perspective shows the relationship between a more operational perspective of open government rather than a regulatory perspective of $\mathrm{FOI}$.

A different perspective for this idea comes from Belanger's (2008) research. In his findings he mentions that citizens trust positively in government and in the use of internet. This kind of trust is not directly related with legitimacy; even though, it compliments a different path of research using technology as a tool to manage and distribute government's information. Relly (2008) supports this idea arguing that telecommunication's infrastructure and free press influence the perceptions of 
government transparency. He also addresses nations which have adopted access-to-information laws and e-government that are reflecting an open government policy; despite the fact that these conditions are not enough to advance in the perception of government transparency.

These authors include technological infrastructure as a key element for open government, in order to consider technology as a platform to improve the diffusion of information and data from the government, which is consistent with recent literature, as of Jaeger and Bertot (2010), both analyzing the open government data along with web 2.0 technologies and crowd-sourcing as a new trend for open government initiatives.

Open government as an information tool has two recent examples: research over the National Security directive declassification by Gordon (2010), that addresses directly one common problem on public administrations and states some regulation approaches, as well as the research of McDermott (2010) who summarizes activities and regulations on the open government initiative of the Barack Obama's administration, launched in the early days of his presidency (White House, 2009). These two examples of one public administration have become leading paths for several governments around the world. However their perspective is only administrative and is used as a tool.

A combined perspective between $\mathrm{FOI}$ and open government is a framework that proposes the idea of stewardship and usefulness (Dawes, 2010). The first idea presents government information as a public good and focuses on assuring security, accuracy, validity and management of public information. This establishes on one side the regulatory purpose of the government as a gatekeeper and on the other side promotes the idea of a citizen obligation and sharing of responsibility of the data along with the government. Also the usefulness principle focuses on increasing public value by enhancing public access to government information and making the reuse of information possible. This second side could be more oriented to citizens' collaboration and cooperation sharing and enhancing public information.

The third direction of open government is focused on data. The open data perspective is a path to understand openness and transparency. It has become a fundamental step to achieve a wider implementation. The European Directive on re-use of public sector information could be a good example of this direction (Katleen, 2011). The international comparison of open data strategies is a comprehensive study on this direction (Huijboom \& Van den Broek, 2011). But Reggi's (2011) research of the benchmarking of open data in the European Union structural funds, presents a more detailed approach of this kind of perspective of open government, and shows the advances and lacks of the different European countries' strategies. Scholl (2011) gives another example of the use of data and open government in collaboration and citizen participation initiatives between the US and Mexico. In a more operational perspective, research from Thacker (2011) on electronic services as a way to open data in order to provide a better citizen services is another way to understand open government services. Copeland and Linders (2011) analyze the open government directive (OGD) in the US. They identified five critical points to challenge the 
implementation of this kind of directive: 1. Directive is focused on technology; 2 . There is a lack of integration with existing legislation and regulations; 3 . Lack of solid definitions of critical terms and thresholds; 4. Diverge and ambiguous goals and 5. Uncertain sustainability (p. 389-390).

The third direction of open government through open data is an operational path of the open government strategy, but lacks in direction as Copeland and Linders (2011) point out. Some questions remain unsolved: What data will be relevant to be opened? Who decides the amount and level of openness of the data? Research on this direction shows some relevant efforts European efforts - but without direction or meaning to achieve a more open government strategy.

The three directions of open government could be complemented or analyzed separately. However, the three of them have two main challenges in common: the lack of assessment and the absence of a citizen perspective. Previous research provides evidence that these open government initiatives are to push government openness, or to push over trust and legitimacy of the government actions. Under this perspective there are few actions to assess the degree of openness or transparency a government achieves with a certain strategy - FOI - or actions - open data. The absence of assessment also could reveal the lack of political support for a coherent egovernment strategy.

One of the few examples of assessment of open government is the research of Hazell (2010) which assesses the performance of the UK FOI Act with a comparative perspective against Canada, Ireland, Australia and New Zealand, remarking the need of research on implementation and strategy.

In the case of Mexico, assessing open government success or pitfalls comes from Lopez Ayllon's (2005) research on the Mexican legislation of transparency implementation in the three levels of government, and Ramos Priego's (2005) research on Mexican websites. Later on Sandoval-Almazan's (2009) research on local government websites for transparency and the benchmarking of Mexican transparency portals (Sandoval-Almazan, 2010).

This gap in the research field of open government justifies the need for a concrete vision to assess open government initiatives.

The absence of a citizen perspective has led to a few researches on citizens' surveys - as Belanger (2008) and Grimmelikhuijsen (2010) - in order to understand their information needs and requirements. Open government is focused on the government official's vision, or the scholar vision about the subject but not the citizen's point of view.

Despite the fact that the Mexican or international cases have in common a lack of citizen direction, there is also a lack of theoretical orientation based on the understanding of an open government concept. The term "Open Government" can be understood through different optics. One optic could be the stakeholder, as the open government directive of the Obama's Administration or the Open government data stakeholder survey (Martin, Kaltenbck, Nagy, \& Auer, 2011). 
Another optic could be the citizen's perspective based on open data or freedom of information; some scholars and researchers provide wider options (Nam, 2011).

Grimmelikhuijsen (2010) defines a model of open government related to transparency through a "process and event model in which a process can be made transparent...". Also, the decision making process and the policy outcome can be transparent (p. 11).

Obama's Open Government Directive interprets open government by building a system based on three principles: "transparency, public participation and collaboration."

Dawes (2010) in order to provide a deeper understanding of the concept outlines four different kinds of understanding:

1. The alternative view of transparency;

2. Data quality and the measurement challenges that refer to the different data quality and metrics to assess the government's performance;

3. The program design and the management challenges which emphasize the management and design of information to access the programs;

4. Information sharing challenges those refer to the intra-governmental information sharing.

Finally Dawes suggests that the stewardship and usefulness concepts are a contribution to this understanding.

According to the previous ideas, Open Government could be understood as an integrated platform to drive government data into openness and accountable information for citizens. For the purpose of this research, the open government idea is more than a trend or a technical perspective and is based on a complete platform with legal components and technological advances in order to pursue its main goal.

The previous three directions are not absolute and do not completely defined the whole field of open government. They present an overview of an ambiguous and unclear field with more directions and doubts rather than answers or clear pictures to point out the future of open government. Because of this reason, this proposal of an assessment model intends to provide some direction to the field and organize in a more logical manner these ideas to provide direction.

The following framework integrates the vision of the government and also tries to integrate the citizen's perspective, making it easy to understand and to assess independently in which stage or situation the open government could be.

\section{Assessment Model}

Governments are the largest information producers. Public policy and decision making are made by information inputs. Even though, assessing the quality and the quantity of information has not been measured yet. In fact, the evaluation of the use of electronic government has become a recent trend and is not completely defined. Kunstelj \& Vintar (2004) explain “... this problem is a 
symptom of pressure from politicians for rapid results encouraging citizens and businesses to move over to using e-services.

The quality of information in the government, the speed and the updated systems are not on discussion on this paper. The main goal is to assess the openness and transparency using Web sites. Assessment is understood as the rate of amount of something; assessing openness is directly related to the evaluation using certain metrics, variables or factors to produce an articulated measurement.

According to this idea, the most related evaluation research of open government portals is directly related to e-government implementations. These are measured by readiness metrics or benchmarking like the UN index, the Brown University reports and the Accenture and Cap Gemini surveys (Jansen (2011). Following this idea, assessing open governments means to understand the degree of accomplishment of the goal of transparent and accessible government information available to citizens and public servants.

This idea of assessment for open government implementations has very limited research (Chapman, 2006). A previous model has been proposed by Kalampokis et.al.(2011) but focuses only on open government data and does not include the whole process of implementation of open government. This model presents four stages: 1. Aggregation of government data; 2. Integration of government data; 3 . Integration of Government Data with non-government formal data and 4. Integration of government data with non government formal and social data. However the store of information - historical and recent files - are the ones able to be opened and continuously be opened because we can considerer them as a public good.

With this idea in mind, government openness can be understood as a system process on a platform as O'Reilly states (Lathrop \& Ruma, 2010). David Easton (1953) developed a political systems framework which resembles an open government, including the same elements.

Easton (1965) describes five components in his model: inputs, outputs, black box, environment and feedback. Open Government could be understood as a system that receives information inputs - from the citizens or the political environment, builds a decision on the black box, and produces a decision or policy (outputs). This is immersed in a well defined environment - political system or constitutional rules - in which it maintains - in theory - a continuous feedback among citizens. (See Figure 1).

Figure 1. The Two Door Model for Open Government 


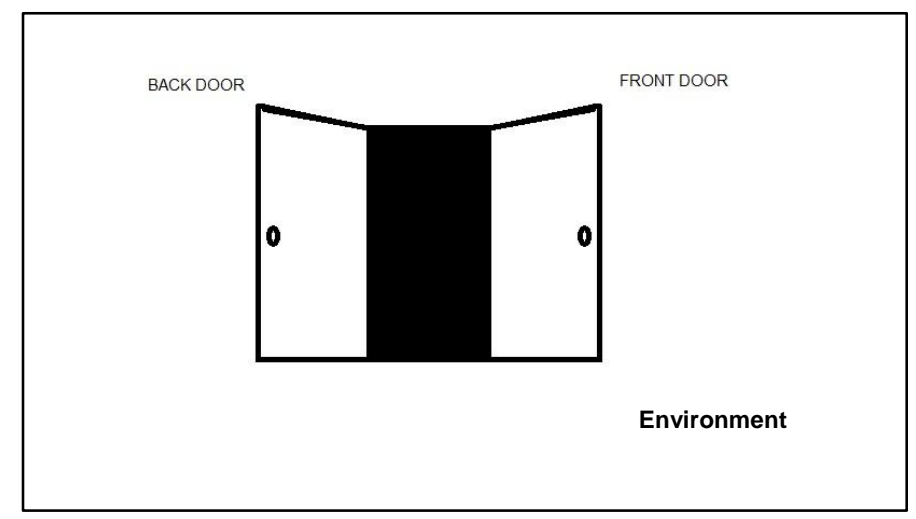

This will be the ideal part of the open government system. However, reality shows that open government initiatives are debated on two main focuses: the rhetorical perspective of politicians who present open government initiatives as a way to justify democratic means; and the second focus is the public administration that becomes the doorkeeper releasing information drop by drop to citizens and public organizations. I call this approach: the two door perspective. (See figure No. 2).

The back door perspective is the government keeper. This focus maintains the old idea that the government is the information owner, and all the data - developed, kept or retrieved by government officials - must be kept away from citizens. This is the actual perspective of several open government initiatives. They want to slightly open the back door of government information and to release some drops of information into the public using ICTs, like websites and web 2.0 tools. However, information is not completely released.

Figure 2. The Two Door Model for Open Government

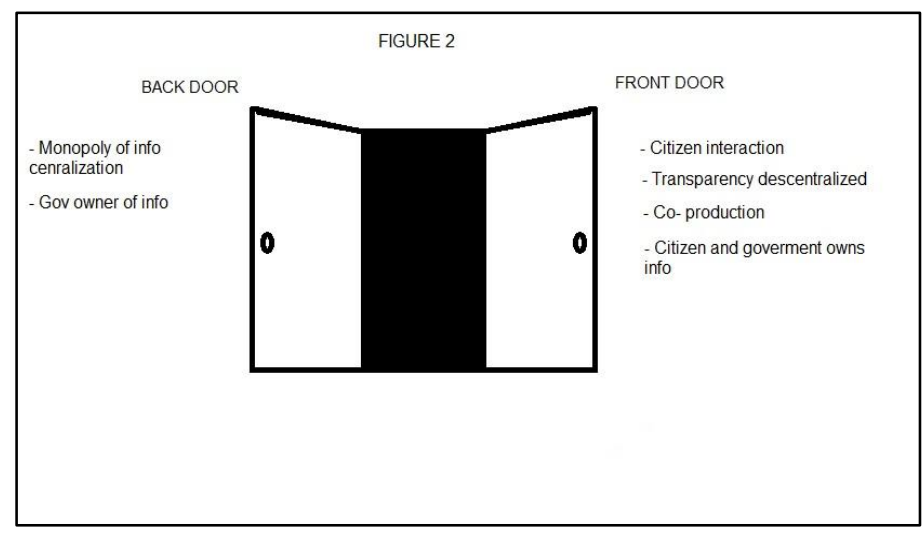

On the other hand, the front door perspective represents the political discourse. It is the ideal goal to achieve in open government. Citizens' expectations about open government refer to an 
open policy in which citizens can take the control of information, can retrieve any data or document, consult files, make questions and handle the same information as government officials. In this perspective, gatekeepers are just ITCs interfaces, databases to enhance citizen information control and dominance. The freedom of citizens to interact with government information is the best way to understand the open government evolution.

However, there is still the black box which is in the middle of both doors. The processing box, were decision making takes place, is not transparent and limits information. Mostly the criteria of decision, the paths of choice and decision process remain hidden. In this component, political solutions are made without citizens' supervision. This black box will be the last stage to open initiatives in the open government.

The front and back door perspectives are related to actual open government initiatives. Table 1 describes their main features and differences of each side. This paper introduces this idea as a way to understand the direction of different open government initiatives.

Table 1. Two Door Model Features

\begin{tabular}{|l|l|l|}
\hline Features & \multicolumn{1}{|c|}{ Back Door Perspective } & \multicolumn{1}{c|}{ Front Door Perspective } \\
\hline Premise & $\begin{array}{l}\text { Government Controls the } \\
\text { information flows }\end{array}$ & $\begin{array}{l}\text { Citizen \& Government Controls of } \\
\text { information flows }\end{array}$ \\
\hline Ownership & $\begin{array}{l}\text { Government is the owner of } \\
\text { information }\end{array}$ & $\begin{array}{l}\text { Information is a public good. Citizens and } \\
\text { government are co-owners }\end{array}$ \\
\hline Direction & Open the Government & Government Transparency \\
\hline
\end{tabular}

\subsection{The Back Door Perspective}

The premise of this perspective is that the government controls the information flows and decides what kind, quality and type of information can be released for public consumption. This idea is more related to the freedom of information perspective, and less from the citizen trust or the NPM perspective.

The leading idea is that information security must be a priority to maintain social control. For such reason information flows must be contained. However, this was a notion of the cold war or a differently connected world. Due to recent technological advances - such as Internet - to maintain this idea is quite difficult. The case of Wikileaks demonstrated that the lack of openness of government information could cause serious disruptions when it becomes public.

On the other hand, governments could take advantage of the citizen perspective and promote cooperation, collaboration and participation in public initiatives considering security, database problems, policy making, etc.

Following this idea, the ownership of the information becomes also the monopoly of information. Government is not only the larger producer; it also monopolizes the production, distribution and 
storage of information. This is not consistent with democratic trends. However, these tasks production, distribution and storage - must be shared with citizens, public experts and academics, in order to generate more valuable information and to make better decisions and public policies.

Finally, the main direction of this perspective is to open the government. However this sense of "openness" could be understood in different degrees, it can be in a fast or a slow way, with high or poor quality information. This means to open the door slightly and close it, or to open it fast and close it slow, but never leave it completely open.

\subsection{The Front Door Perspective}

According to this perspective, government and citizens have a common goal: to share information. Because information is a public good, both have the same rights and obligations. Information becomes, in this perspective, a good to be maintained and cared for the public benefit. In this sense, the concept of co-owner becomes a collaborative and a cooperative task. Citizens and government - means of public administration - are partial owners, developers and keepers of all public information.

On this perspective the common task becomes relevant and more positive to build governmentcitizen interaction. The way government shares and receives information is the same way citizens produce this kind of cooperation. Technology plays a central role in this perspective, where a platform becomes an intermediary to facilitate this kind of collaboration.

Table 2 describes some examples of different components of the two door models that can be tested.

\begin{tabular}{|c|c|c|}
\hline & Back Door Perspective & Front Door Perspective \\
\hline Elements & $\begin{array}{l}\text { - Creates new information channels for } \\
\text { government outlets } \\
\text { - Reduces corruption exposing some } \\
\text { laws and regulations } \\
\text { - Monitors government activities and } \\
\text { publicizes } \\
\text { - Reduces formats and government } \\
\text { transactions }\end{array}$ & $\begin{array}{l}\text { - Interacts with citizens addressing } \\
\text { interests and information concerns } \\
\text { - Reduces the digital division among } \\
\text { citizens to promote more government } \\
\text { openness } \\
\text { - Publicizes government process } \\
\text { - Enhances public database to be reusable } \\
\text { and dynamic } \\
\text { - Enables citizen's interaction with } \\
\text { government officials, programs and an } \\
\text { inside process to co-produce information } \\
\text { and data } \\
\text { - Government officials are easy to reach } \\
\text { by any communication means }\end{array}$ \\
\hline
\end{tabular}




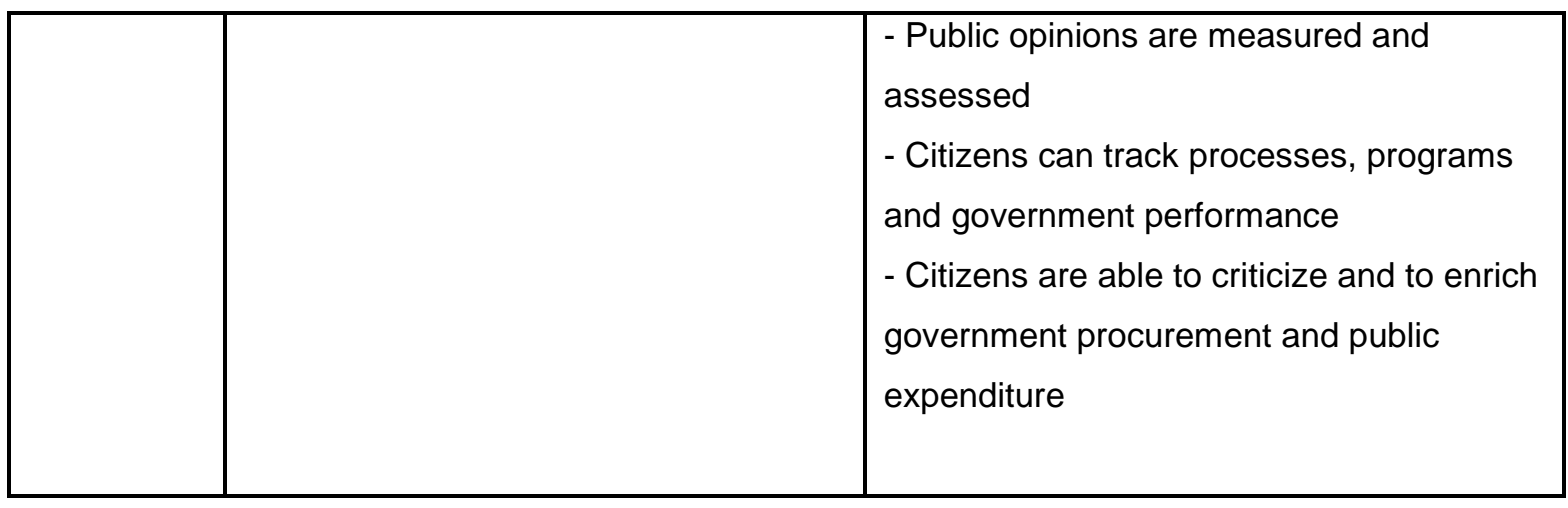

These components must be tested and adapted with the empirical evidence and a constant evaluation or metrics. They are not definite or exclusive from one side or the other of the model. , They are only paths to interpret and to organize data from this perspective.

\section{Model Discussion}

The two-door model is useful for explaining on which side of the model the open government initiative is working. For example, initiatives linked with citizen participation and the use of social media, that allows getting data almost immediately and without intermediaries are considered to be from the front door perspective.

On the contrary, an initiative that promotes government control - normative or practical - and reduces citizen participation, considering public information as a monopoly or a centric vision will be considered from the back door initiative.

In order to provide a richer perspective of the two-door model, Table 3 describes the link between the three directions of open government discussed in the second section of the paper, and the two door model, with some examples in order to suggest a more orderly framework to help understand the directions of different initiatives of open government. These examples are placed accordingly to their characteristics and the features of the model. However they might need an empirical validation as well as the model itself. According to this, the freedom of information perspective (FOI) is better explained by the back door elements, because relations on the government side are looking forward to controlling the output of information and the information products. This is sometimes linked to the centralization perspective or to the slight opening of information to citizens.

Table 3. The three directions and the Two-Door Model with examples

\begin{tabular}{|l|c|c|}
\hline & Back Door Perspective & Front Door Perspective \\
\hline 1. Freedom of & ICT and eGovernment: European Action & $\bullet \quad$ the National Security \\
\hline
\end{tabular}




\begin{tabular}{|l|l|l|}
\hline $\begin{array}{l}\text { Information } \\
\text { Perspective FOI }\end{array}$ & $\begin{array}{l}\text { Plan 2011-2015 } \\
\text { O Open Government Partnership }\end{array}$ & directive declassification \\
\hline $\begin{array}{l}\text { 2. Open Government } \\
\text { as a tool }\end{array}$ & Open Government Directive (US) & $\begin{array}{l}\bullet \text { The European Directive } \\
\text { on re-use of public sector } \\
\text { information }\end{array}$ \\
\hline $\begin{array}{l}\text { 3. Open Data } \\
\text { Perspective }\end{array}$ & (Huijboom \& Broek, 2011; Reggi, 2011; Thacker, 2011) (UK) \\
\hline
\end{tabular}

The national security directive declassification and the European directive on re-use of public sector information could be in the front door perspective as basic examples of potential initiatives that could lead to a transformation with more openness. The open government as a tool perspective also better explains the back door perspective, because it is related to instruments and strategies to maintain certain controls and to release some amounts of information, but not a complete "liberation" of information and data as requested in the front door perspective.

However, initiatives from Gordon and McDermott (2010) are more suitable in ideal terms for the front door perspective because they enhance cooperation and co-production from citizens and increase the government-citizen relationship. The stewardship, model as explained before, has this notion of shared responsibility about information. This is why it is more related to the open door perspective.

Other initiatives like the European e-Government Action plan (2011-2015) identifies two main sources of potential benefits: transparency and data re-use. The European directive adopted the re-use of the Public Sector Information (PSI) in 2003 and reviewed it on 2009. Both, transparency and data re-use can be considered as back door examples to slightly open the government files.

Finally the open data perspective could be considered as a previous - or basic - stage for both doors, considering this perspective as a way to interact between citizen and government, making public data available.

\section{Conclusions and Future Research}

This paper's main objective is to develop a model to assess the open government initiatives, in order to try to solve the different perspectives and understandings of the open government field. A more comprehensive and easy way to follow the model is presented here.

The two-door model needs to be tested with empirical evidence to become useful and improve its features and characteristics. The main idea behind the model is to become a tool to organize and classify open government efforts with a direction perspective. There is no room to present a transparency government initiative that leads to nowhere, or becomes a waste of time on public spending. This model exposes directly if the effort is consistent with a strategy of opening the government information or files, or if there are other findings. 
This basic model has its limitations. More research is needed in order to understand the legal framework behind the open government trend. Also, it is important to think about more detailed options to promote and to encourage initiatives of open government so that politicians or ruling parties cannot avoid or deceive citizens. This model is focused more on the outcomes, specifically on the open government websites. A different approach is needed to assess processes and procedures to promote open government. The black box in the middle of both doors must be analyzed and opened to disclose the decision making process and to promote accountability.

Another perspective to consider is the open government evolutionary path. Open government can be understood as a constant construction and development. According to this idea, a first step could be the open data perspective, the next step could be the tools to open the government archives and information, and the final and more utopian step will be the freedom of information itself. Kooper, Maes, \& Lindgreen's (2010) idea of governance of information supports this argument, proposing a common ground - a regulatory one - in which citizens and government officials share the responsibility of information and both can control, collect and distribute information as a common public good and not as a monopoly of information as it is at present. Shepherd's (2010) research in the UK points in this direction, increasing public participation in the release of record management services in local governments. This kind of open government promotes transparency and finally accountability, but of course this is not enough to change the government (Shepherd, Stevenson, \& Flinn, 2010).

Public administration officials and the government as a whole have a long tradition of being the owners of public information. It will be difficult to release this condition and open the files and the process for the real owners: the people. However, the combination of people and government can improve the use of information and decision-making on government issues and public policy. Transparency will improve government relationship and can promote a better accountability of the process and the use of public funding. The two-door model intention is to contribute to such goal and to improve a better understanding of the open government field.

\section{References}

\section{References}

Bertot, J. C., Jaeger, P. T., \& Grimes, J. M. (2010). Using ICTs to create a culture of transparency: E-government and social media as openness and anti-corruption tools for societies. Government Information Quarterly, 27(3), 264-271. doi: 10.1016/j.giq.2010.03.001

Chapman, R., \& Hunt, M. (1986). Open government: a study of the prospects of open government within the limitations of the British political System (2nd ed.).

Comission, E. (2011). ICT and e-Government: European Action Plan 2011-2015. Retrieved from http://europa.eu/legislation summaries/information society/strategies/si0021 en.htm.

Curtin, D., \& Meijer, A. J. (2006). Does transparency strengthen legitimacy? Information Polity, 11(2), 109-122.

Easton, D. (1953). The Political System: an inquiry into the state of Political Science (2nd ed ed.). New York: Alfred Knopf.

Easton, D. (1965). A system analysis of political life. New York: Wiley. 
Francesco De Angelis, A. P., Barbara Re. (2010). E-Democracy: A Solution for Digital Divided Paper presented at the Electronic Government and Electronic Participation: Joint Proceedings of Ongoing Resarch and Pojects of IFIP eGOV and ePart 2010, Lausanne, Switzerland.

Government, U. (2011). Uk Government Licensing Framework Retrieved December 13tth, 2011, 2011, from http://www.nationalarchives.gov.uk/information-management/uk-gov-licensingframework.htm

Grimmelikhuijsen, S. G. (2010). Transparency of Public Decision-Making: Towards Trust in Local Government? Policy \& Internet, 2(1). doi: 10.2202/1944-2866.1024

Hazell, R., \& Worthy, B. (2010). Assessing the performance of freedom of information. Government Information Quarterly, 27(4), 352-359.

Heckmann, D. (2011, January 4 - 7). Open Government - Retooling Democracy for the 21st Century. Paper presented at the Proceedings of the 44th Annual Hawaii International Conference on System Sciences (HICSS 2011), Kauai, Hawaii USA.

Hood, C. (2011). From FOI World to WikiLeaks World: A New Chapter in the Transparency Story? Governance, 24(4), 635-638. doi: 10.1111/j.1468-0491.2011.01546.x

Huijboom, N., \& Broek, T. V. d. (2011). Open data: an international comparison of strategies. European Journal of ePractice.

Jaeger, P. T., \& Bertot, J. C. (2010). Transparency and technological change: Ensuring equal and sustained public access to government information. Government Information Quarterly, 27(4), 371-376. doi: 10.1016/j.giq.2010.05.003

Janssen, M. (2010). Measuring and Benchmarking the Back-end of E-Government: A Participative Self-assessment Approach

Electronic Government. In M. Wimmer, J.-L. Chappelet, M. Janssen \& H. Scholl (Eds.), (Vol. 6228, pp. 156-167): Springer Berlin / Heidelberg.

Kalampokis, E., Tambouris, E., \& Tarabanis, K. (2011). Open Government Data: A Stage Model for

Electronic Government. In M. Janssen, H. Scholl, M. Wimmer \& Y.-h. Tan (Eds.), (Vol. 6846, pp. 235-246): Springer Berlin / Heidelberg.

Katleen, J. (2011). The influence of the PSI directive on open government data: An overview of recent developments. Government Information Quarterly, Forthcoming(0). doi: 10.1016/j.giq.2011.01.004

Kooper, M. N., Maes, R., \& Lindgreen, E. E. O. R. (2010). On the governance of information: Introducing a new concept of governance to support the management of information. International Journal of Information Management, In Press, Corrected Proof(Corrected Proof). doi: 10.1016/j.ijinfomgt.2010.05.009

Lathrop, D., \& Ruma, L. (2010). Open Government: collaboration, transparency and Participation in Practice (1st ed.). Usa: O'reilly.

Mantilla, C. C. (2009). e-democracy and inclusion: the role for government agencies in mobilizing participation. Paper presented at the Proceedings of the 3rd International Conference on Theory and Practice of Electronic Governance (ICEGOV), Bogota, Colombia.

Martin, M., Kaltenbck, M., Nagy, H., \& Auer, S. r. (2011, 2011). The Open Government Data Stakeholder Survey Retrieved 30 septiembre 2011, 2011, from http://okcon.org/2011/programme/the-open-government-data-stakeholder-survey

Nam, T. (2011, January 4 - 7). New Ends, New Means, but Old Attitudes: Citizens' Views on Open Government and Government 2.0 Paper presented at the Proceedings of the 44th Annual Hawaii International Conference on System Sciences (HICSS 2011), Kauai, Hawaii USA.

Ojo, A., Janowski, T., \& Estevez, E. (2011). Building Theoretical Foundations for Electronic Governance Benchmarking

Electronic Government. In M. Janssen, H. Scholl, M. Wimmer \& Y.-h. Tan (Eds.), (Vol. 6846, pp. 13-25): Springer Berlin / Heidelberg.

Petrik, K. (2009). Participation and e-democracy how to utilize web 2.0 for policy decision-making. Paper presented at the Proceedings of the 10th Annual International Conference on Digital Government Research: Social Networks: Making Connections between Citizens, Data and Government.

Reggi, L. (2011). Benchmarking Open Data Availability across Europe: The Case of EU Structural Funds European Journal of ePractice.

Sandoval-Almazan, R. (2009). Midiendo la Transparencia en Internet: Ranking de las páginas web de los Institutos de Transparencia en Mexico. In C. Herrera, G. Lizama \& L. Morales 
(Eds.), Federalismo Y transparencia en Mexico: seis estudios de Caso (1 ed., Vol. 1, pp. 219-247). Ciudad de Mexico Alianza Civica-Comunidad Europea.

Sandoval-Almazan, R. (2010). Ranking de Portales de Transparencia: La medición 2010. Política Digital, 30-37.

Shepherd, E., Stevenson, A., \& Flinn, A. (2010). Information governance, records management, and freedom of information: A study of local government authorities in England. Government Information Quarterly, 27(4), 337-345.

Thacker, M. (2011). Open Linked Data to Inform Policy and Improve Services. European Journal of ePractice.

White House. (2009). Memorandum on Transparency and Open Government. Washington D.C.: White House Retrieved from http://edocket.access.gpo.gov/2009/pdf/E9-1777.pdf.

\section{About the Author}

\section{Rodrigo Sandoval-Almazan}

Rodrigo Sandoval-Almazán is an Assistant Professor in the Research Center of the Business College in the Autonomous University of the State of Mexico, in Toluca, Mexico. He has lectured on topics such as Information Systems for business, electronic commerce and open government. His research interests include electronic government, social networks, digital metrics, and open government. 